\title{
GEOLOGY OF THE YELLOWSTONE-TETON REGION
}

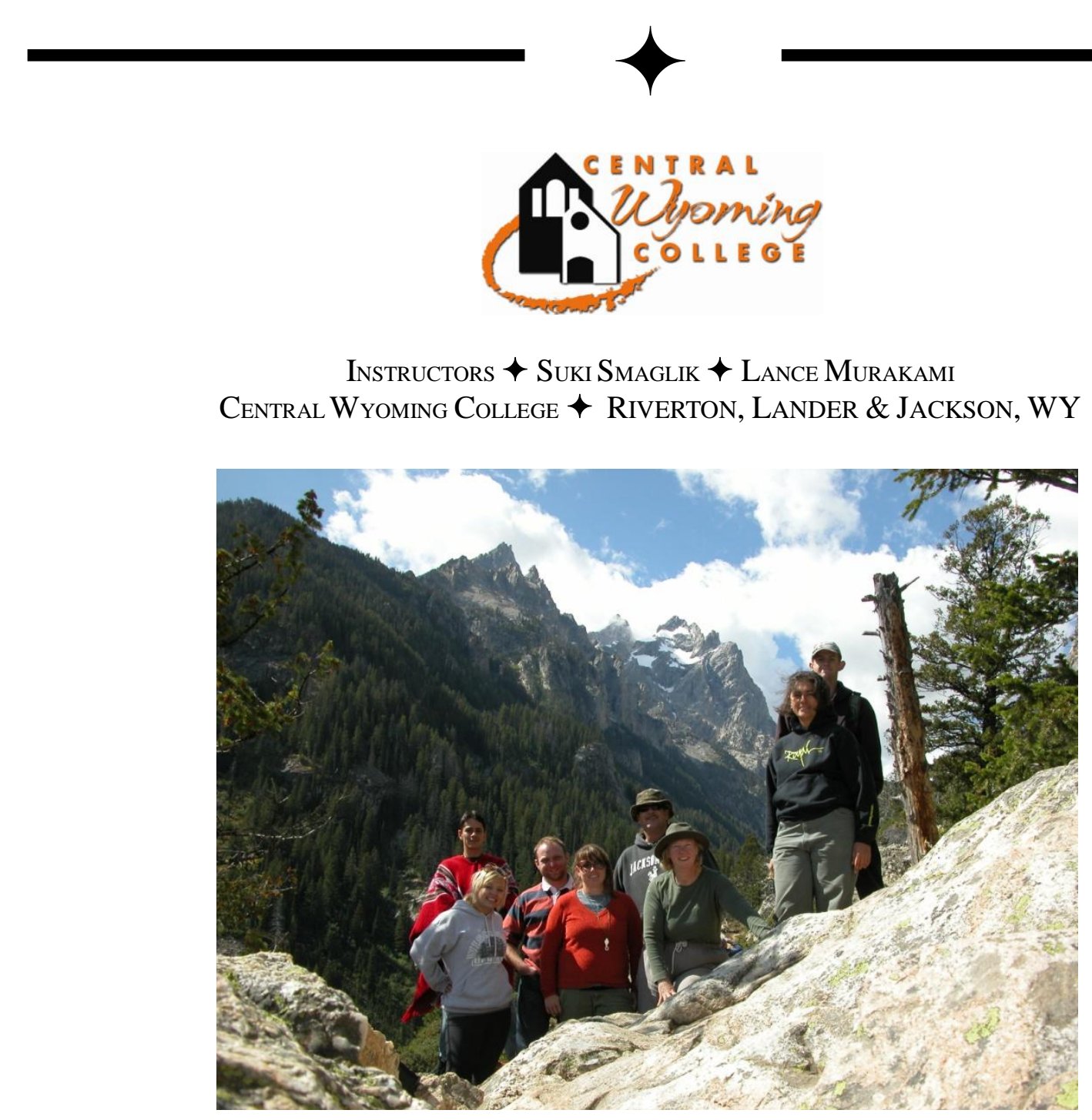

Figure 1. Suki Smaglik (center front in hat) led seven CWC students on a boat trip across Jenny Lake, and a climb to Inspiration Point and beyond, while observing and explaining the geologic history of the Tetons. (17 Sept., 2011)

\section{Class Overview}

GEOL 1240 Geology of the Yellowstone-

Teton Region is offered as a 1 credit, 3-day trip each September, through Central Wyoming College (CWC). Each year the itinerary varies and students may earn 2 credits toward graduation by repeating the course. CWC Student Activities covered the cost of transportation for this year's trip. Students participating on these trips do not need to be geosciences majors, although this year six of the seven involved have a strong interest in a geosciencerelated career.

In 2011, the emphasis was on the Teton area and base-camp was held at the AMK Ranch. The 2011 Itinerary included:

- Dubois - Wind River/Absaroka Overlook

- Togwotee Pass - Absaroka Volcanics 
- Togwotee Pass - Harebell Quartzite Conglomerate (History of the Tetons Exercise)

- $\quad$ String Lake - Teton Fault Hike

- Jenny Lake - boat ride

- Inspiration Point Hike - History of Tetons

- Old Faithful \& West Thumb biogeochemistry

- Lewis Falls - Obsidain Flow Structure

- Signal Mountain - Glacial features overlook

- Gros Ventre Landslide - Geologic Hazards Exercise

The wet weekend was a nice relief from the summer heat. Our first exercise at the Harebell Formation Conglomerate consisted of field observations and a "geologic cartoon" matching exercise that requires only observations and logic (no prior geology knowledge).

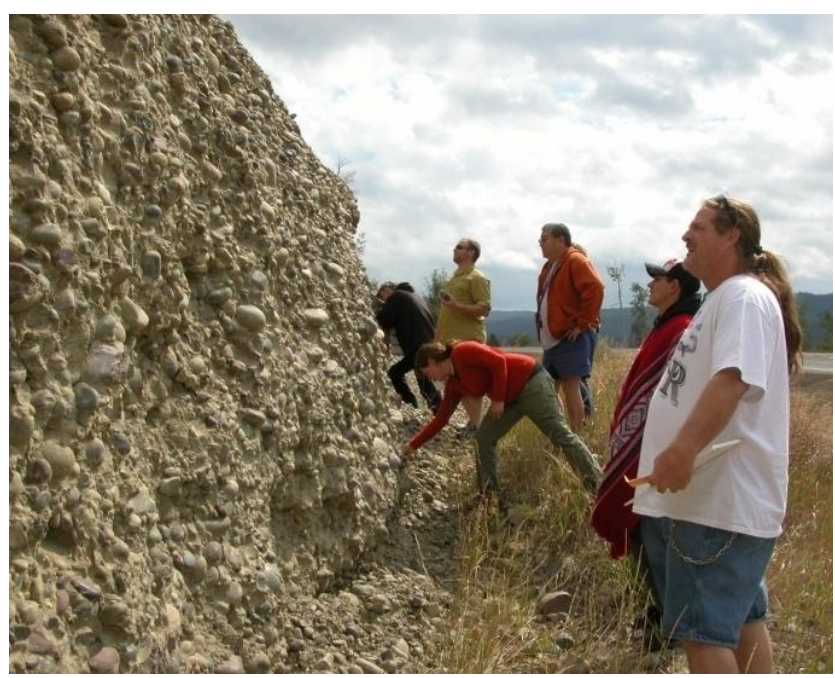

Figure 2. Students collecting rocks from sediment deposits.

After making observations on site, we proceeded to the Grand Teton NP Visitor's Center to discuss and review the exercise. Always being prepared with an alternative site is good, as we were able to continue our discussion under the protection of the covered walkway around the center!

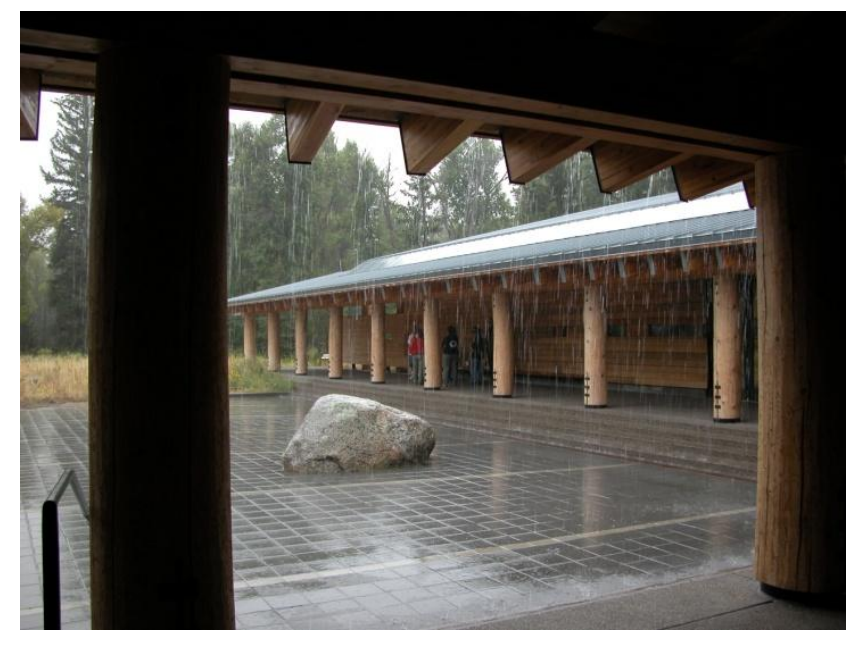

Figure 3. Grand Teton National Park Visitor's Center.

The weather cleared enough for an informative hike along the Teton Fault, above String Lake.

The highlight of our trip was a boat ride on Jenny Lake to the Inspiration Point trailhead were we discussed the different types of ancient "hard" rocks that make up the bulk of the Tetons. It was a beautiful fall day that left us all inspired to learn more about the area.

We were also able to compare and contrast the Teton area geology with some of the hydrothermal features of Yellowstone, including some first-time viewing of an Old faithful eruption.

The final day of the trip focused on geologic hazards, with visits to Signal Mountain for an overview of the Teton Valley landscape, a brief stop at the Jackson Lake Dam and a final exercise at the Gros Ventre Landslide.

We are grateful for the use of the UW-NPS Research Station as our base camp for this trip. 